\section{MAXIMUM EFFORT TRAINING PERFORMED IN HYPOXIA ALTERS THE MOOD PROFILE}

\author{
EXERCICIO FÍSICO MÁXIMO REALIZADO EM HIPÓXIA ALTERA O PERFIL DEHUMOR
}

EJERCICIO FISICO MÁXIMO REALIZADO EN HIPOXIA ALTERA EL PERFIL DEL ESTADO DEÁNIMO

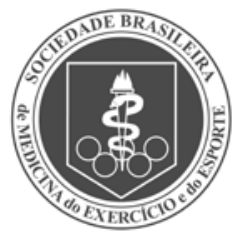

Original Article ARtigo Original Artículo Original
Sara Quaglia de Campos Giampá (Physical Education Professional) Jorge Fernando Tavares de Souza ${ }^{2,3}$ (Physical Education Professional)

Marco Túlio de Mello 4

(Physical Education Professional)

Sergio Tufik² (Physician)

Ronaldo Vagner Thomatieli

dos Santos $1,3,5$

(Physical Education Professional)

Hanna Karen Moreira Antunes 1,3,5

(Physical Education Professional)*

1. Interdisciplinary Health Sciences Graduate Program, Universidade Federal de São Paulo, Campus Baixada Santista, Santos - SP, Brazil. 2. Department of Psychobiology, Universidade Federal de São Paulo, Campus São Paulo, São Paulo, SP, Brazil.

3. Laboratório Interdisciplinar em Fisiologia e Exercício - LAIFE,

São Paulo, SP, Brazil;

4. Escola de Educação Física, Fisioterapia e Terapia Ocupacional, Universidade Federal de Minas Gerais, Belo Horizonte, MG, Brazil. 5. Department of Biosciences, Universidade Federal de São Paulo, Campus Baixada Santista, Santos, SP, Brazil.

\section{Correspondence:}

Hanna Karen M. Antunes Universidade Federal de São Paulo - Campus Baixada Santista, Department of Biosciences/Campus Baixada Santista.

Rua Silva Jardim, 136, Térreo, Vila Mathias, Santos, SP, Brazil. 11015-020.

hanna.karen@unifesp.br

\section{ABSTRACT}

Introduction: Physical exercise at high altitude has become constant. However, the risks associated with this type of exercise represent a major concern, considering the influence of important stressors such as hypoxia and physical exercise on psychobiological and physiological responses. Objective: Analyze the mood state and behavior of physiological variables of volunteers subjected to a progressive loading protocol until they reached maximum volitional exhaustion, both at sea level and at a simulated altitude of 4500 meters. Method: For both conditions studied, the volunteers responded to two instruments that assess mood responses: The Brunel Mood Scale and the Visual Analogue Mood Scale. They also underwent blood sampling to measure blood lactate levels and to evaluate oxygen-hemoglobin saturation. These procedures were performed before, immediately after, and 30 and 60 minutes after the end of the protocol. Results: Hypoxia triggered negative effects on mood responses, especially when compared to sea level conditions. An increase in fatigue level $(p=0.02)$ and mental confusion ( $p=0.04)$ was observed immediately after the exercise session, and reduction of vigor ( $p=0.03$ ) was noted at 30 minutes, accompanied by a reduction in oxygen-hemoglobin saturation immediately after the session and at 30 minutes. There was also an increase in blood lactate levels immediately after the session $(p=0.006)$. Conclusion: The particularities of the hypoxic environment associated with maximum exercise are able to cause a deterioration of mood and physiological responses, which can negatively modulate physical performance. This is a cross-sectional clinical study.

Keywords: Mood; Exercise; Exercise test; Hypoxia.

\section{RESUMO}

Introdução: A prática de exercícios físicos em elevadas altitudes tem se tornado constante. Entretanto, os riscos associados a esta representam uma grande preocupação, considerando a influência de importantes agentes estressores, como hipóxia e exercício físico, sobre as respostas psicobiológicas e fisiológicas. Objetivo: Analisar o perfil do humor e c comportamento de variáveis fisiológicas de voluntários submetidos a um protocolo de cargas progressivas atéa Exaustão Voluntária Máxima no nivel do mar eem altitude simulada de 4.500 metros. Métodos:Para ambas as condições estudadas, os voluntários responderam a dois instrumentos que avaliam as respostas do humor, Escala de Humor de Brunel e o Visual Analogue Mood Scale, eforam submetidos à coleta de sangue para verificar a concentração de lactato sanguíneo, bem como para avaliar a saturação de oxi- hemoglobina. Esses procedimentos foram realizados antes, imediatamente depois e 30 e 60 minutos após o término do protocolo. Resultados: A hipóxia desencadeou efeitos negativos sobre as respostas de humor, principalmente com relação ao nível do mar. Verificou-se aumento da fadiga $(p=0,02)$ e da confusão mental $(p=0,04)$ imediatamente após a prática e redução do vigor $(p=0,03)$ aos 30 minutos; acompanhadas da diminuição da saturação da oxi-hemoglobina imediatamente após e aos 30 minutos; constatou-se ainda, o aumento da concentração de lactato sanguíneo no momento imediatamente após $(p=0,006)$. Conclusão: As particularidades do ambiente hipóxico associadas à realização do exercício físico máximo são capazes de piorar o estado de humor e as respostas fisiológicas, o que pode modular negativamente o desempenho físico. Este estudo é do tipo clínico transversal.

Descritores: Afeto; Exercício; Teste de esforço; Hipóxia.

\section{RESUMEN}

Introducción: La práctica de ejercicios físicos en elevadas altitudes se ha vuelto constante. Entretanto, los riesgos asociados a ésta representan una gran preocupación, considerando la influencia de importantes agentes estresantes, como hipoxia y ejercicio físico, sobre las respuestas psicobiológicas y fisiológicas. Objetivo: Analizar el perfil del humor y el comportamiento de variables fisiológicas de los voluntarios sometidos a un protocolo de cargas progresivas hasta el Agotamiento Voluntario Máximo, al nivel del mary a una altitud simulada de 4500 metros. Métodos: Para ambas condiciones estudiadas, los voluntarios respondieron a dos instrumentos que evalúan las respuestas del humor: la Escala de Humor de Brunel y el Visual Analogue Mood Scale, y fueron sometidos a colecta de sangre para verificar la concentración de lactato sanguíneo, bien como para evaluar la saturación de oxihemoglobina. Estos procedimientos fueron realizados antes, inmediatamente después, y 30 y 60 minutos después de finalizar el protocolo. Resultados: La hipoxia desencadenó efectos negativos sobre las respuestas de humor, principalmente con relación al nivel del mar. Se verificó aumento de fatiga $(p=0,02)$ y de la confusión mental $(p=0,04)$ inmediatamente después de la práctica y reducción del vigor $(P=0,03)$ a los 30 minutos; acompañadas de la disminución de la saturación de la oxihemoglobina 
inmediatamente después y a los 30 minutos; se constató además el aumento de la concentración de lactato sanguíneo en el momento inmediatamente después $(p=0,006)$. Conclusión: Las particularidades del ambiente hipóxico asociadas a la realización del ejercicio físico máximo, son capaces de empeorar el estado de humor y las respuestas fisiológicas, lo que puede modular negativamente el desempeño físico. Este estudio es del tipo clínico transversal.

Descriptores: Afecto, Ejercicio, Prueba de esfuerzo, Hipoxia.

\section{INTRODUCTION}

Countless people seek adventure and leisure, as well as practice physical exercises (PE) at high altitudes, directly exposing themselves to the consequences of reduced oxygen partial pressure of hypoxia'.

Hypoxia represents a threat to homeostasis, as it reduces an organism's ability to bind, transport, and use oxygen through the combined functions of the respiratory, cardiovascular, and hematological systems ${ }^{1}$. These threats are counteracted by immediate physiological responses that induce physiological alterations, for example variations in heart rate (HR), systolic volume, cardiac output, muscle blood flow, ventilation, use of energy substrates, and mitochondrial function have been observed in the autonomic nervous system ${ }^{2,3}$.

At high altitudes, the maximum capacity of PE, time of resistance, and performance are reduced, in contrast to the increase in general fatigue. Such consequences are related to the combined effects of three important factors: 1 ) reduction in the partial pressure of oxygen, resulting in a lower supply and utilization of oxygen by the skeletal muscles; 2) reduction of atmospheric density and its important impact on air resistance; and 3 ) the process of acclimatization to altitude, which in turn can affect oxygen transportation ${ }^{3-5}$.

In this context, in addition to the physiological responses of the combined stress of hypoxia and PE psychological capacities such reactiveness, attention, cognitive performance, mental efficiency and mood responses (including anxiety) are also influenced and impaired ${ }^{6-8}$.

Lemos et al. ${ }^{9}$ observed that men exposed to hypoxia simulated at 4.500m exhibited increased scores in affective dimensions such as depressive mood, anger, and fatigue. In addition, vigor, attention, visual memory, working memory, concentration, executive function, inhibitory control, and mental processing speed deteriorated in this environmental condition.

These losses represent significant risks that are influenced by the cognitive appraisal of physiological responses, and thus, more precisely, mood responses serve as early indicators of the adverse effects of this condition $^{10}$, consistent with Bahrke and Shukitt-Halle ${ }^{11}$ that posit that environmental changes tend to influence psychological functioning before physiological functioning.

The association between psychological function and PE in normoxia is well established and the improvement of cognitive behavior and affective experience has been emphasized ${ }^{12}$, encompassing an enhanced psychological well-being with a concomitant reduction of tension, anger, depression, and confusion ${ }^{13}$.

This study aims to elucidate the mood profiles of participants undergoing an PE regime performed under maximum voluntary ventilation and a simulated hypoxia condition and investigate possible associations with physiological factors and contribute to the detection of environmental stress.

\section{MATERIAL AND METHODS}

The study involved 12 physically active men, with a mean age of $21.92 \pm 2.07$ years, height $1.76 \pm 0.04 \mathrm{~m}$, total body mass of $70.36 \pm$ $10.83 \mathrm{~kg}$, and body mass index of $22.69 \pm 3.42 \mathrm{~kg} / \mathrm{m}^{2}$. To confirm their cardiovascular health, the participants performed a resting electrocardiogram and an exercise stress test, and those deemed suitable were recruited to the study and participated in a progressive regimen of loads until maximum voluntary ventilation (TEmax), carried over in two experimental conditions, with an interval of 7 days between them: 1) Sea level; 2) Simulated hypoxia at an altitude of 4500 meters.

The study was approved by the Ethics Committee of the Federal University of São Paulo/ São Paulo Hospital (\#0620/09). All participants signed an informed consent form.

The tests were performed at the same time on a treadmill (Lifefitness ${ }^{\circledR}$ $9700 \mathrm{HR}$, Schiller Park, IL, USA) with a fixed inclination of $1 \%$ in order to simulate physical exercise in open places ${ }^{14}$. The TEmax protocol consisted of speed increments of $1 \mathrm{~km} / \mathrm{h}$ every minute, with an initial warm-up load of three minutes at $7 \mathrm{~km} / \mathrm{h}$. The test ended when a participant reached maximum voluntary ventilation; this was regarded as the incapacity to sustain the speed of the treadmill over 15 seconds, or until the participants request to stop the test even when encouraged verbally.

At sea level condition, ergo-spirometry was performed to determine the following respiratory variables: peak oxygen consumption, oxygen consumption at ventilatory threshold l, oxygen consumption at ventilatory threshold II, maximum HR, HR at ventilatory threshold I, HR at ventilatory threshold II, maximum speed, speed at the intensity of the ventilatory threshold I and speed at the intensity of the ventilatory threshold II.

These variables were methodologically obtained by measuring respiratory gas exchange with a metabolic system (COSMED model Quark PFT - Pulmonary Function Testing - FRC \& DLCO, Italy). The system was calibrated prior to the completion of each protocol using a known gas concentration. A Hans Rudolph ${ }^{\circledR}$ flow-by face mask (Kansas City, MO, USA) was used.

The tests performed in the simulated hypoxia condition were conducted in a normobaric chamber (CAT-Colorado AltitudeTraining ${ }^{\mathrm{TM}} /$ CAT-12 Air Unit), consisting of a microprocessor system capable of reading electrical signals from two oxygen sensors, and a carbon dioxide and an atmospheric pressure sensor. The information from these sensors are linearized and used to calculate the simulated altitude, to be able to regulate and control the air units, purifiers, and fans to sustain the desired altitude.

In each experimental condition the participants partook in subjective and physiological assessments. These evaluations were performed before, immediately after, and 30 minutes and 60 minutes after the end of the TEmax. In the tests conducted in the hypoxia condition, participants were evaluated immediately after the experiment, 30 minutes after, at sea level at baseline, and 60 minutes after (Figure 1).

\section{Evaluation of Mood}

1. Brunel Mood Scale (BRUMS): Developed to measure mood ${ }^{15}$, this instrument was adapted from the "Profile of Mood States" (POMS)16, validated for the Portuguese language ${ }^{17}$. It consists of a list of 24 mood related adjectives, where participants note what they feel in relation to each adjective, using a Likert scale of 0 to 4.

2. Visual Analogues of Mood SCAles (VAMS): Consists of 16 100-mm analog scales that are used to assess changes in participants' mood by marking on a vertical line ${ }^{18}$.

\section{Physiological evaluation}

1. Blood lactate: Samples of $25 \mu \mathrm{L}$ of arterial blood were collected from the earlobe through a heparinized capillary. The blood was immediately 


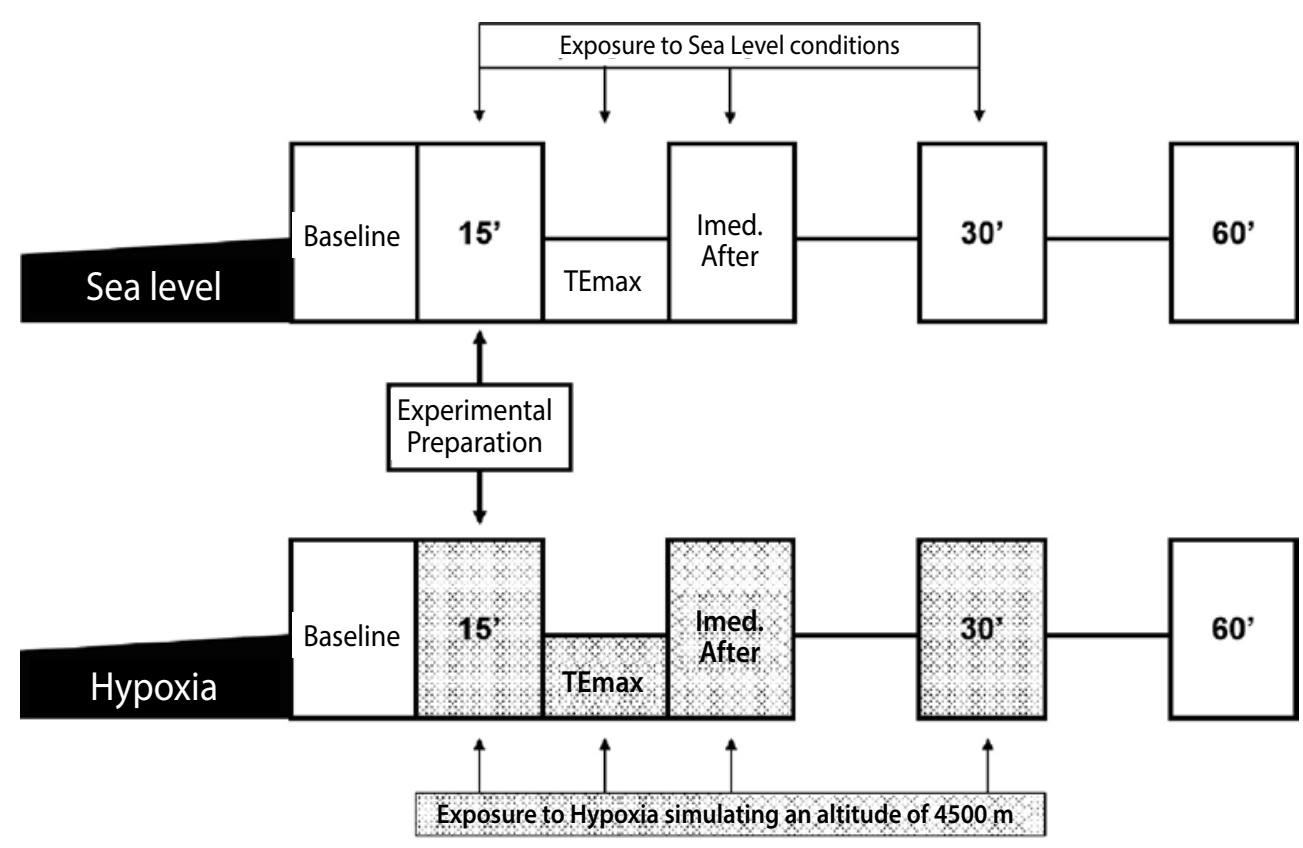

Figure 1. Experimental design followed by 12 volunteers undergoing a TEmax regimen in two experimental conditions, sea level and hypoxia simulated at an altitude of 4,500 meters. The experimental preparation of the participants was 15 minutes, allowing participants to be placed and prepared in the chamber for the beginning of the procedure. After these adjustments, the participants commenced the TEmax. Subjective and physiological evaluations were performed at baseline, follow up (immediately after), 30 minutes, and 60 minutes after TEmax, in their respective experimental conditions.

transferred to $1.5 \mathrm{ml}$ polyethylene microtubules with an Eppendorff-type cap containing $50 \mu \mathrm{L}$ of $1 \%$ Sodium Fluoride (NaF) solution. The samples were analyzed with an electrochemical analyzer (YSI STAT 2300, Yellow Springs, Ohio, USA).

2. Saturation of Oxy-hemoglobin: The measurement of oxyhemoglobin saturation was performed using a digital finger Oximeter (Fingertip Pulse ${ }^{\circledR}$ - Model MD300C202) with a red and infrared optical sensor placed on the fingertip that continuously and non-invasively monitors arterial oxygenation.

\section{Statistical analysis}

The statistical analysis was conducted using Statistica ${ }^{\circledR} 12.0$ software. The normality of data was verified using the Shapiro-Wilk test. Measures of central tendency were calculated for the descriptive data analysis. A repeated measures ANOVA with the factors TIME and GROUP was used to analyze interactions between results. The Duncan post hoc test was used to detect significant differences. The level of significance was set at $p<0.05$.

\section{RESULTS}

Table 1 presents the descriptive analysis of the cardiorespiratory variables of TEmax at sea level.

In the BRUMS instrument (Figure 2 ) results, the sea level condition was found to decrease stress scores $\left(F_{(3.66)}=3.45, p<0.05\right)$ at 60 minutes compared to baseline $(p=0.009)$. A reduction of the vigor scores was observed immediately after the condition $\left(F_{(3.66)}=18.23, p<0.05\right)$, concomitant with increased fatigue $\left(F_{(3.66)}=37.85, p<0.05\right)$, compared to baseline and the 30 and 60 minute intervals.

In the hypoxia condition, a decrease in vigor and increased fatigue were observed immediately after ( $p=0.00002$ both dimensions) and 30 minutes later (vigor: $p=0.0005$; fatigue: $p=0.003$ ); participants remained in the normobaric chamber. After 60 minutes, vigor scores $(p=0.04)$ were higher than baseline values unlike fatigue scores.

Hypoxia resulted in an increased aggressive quality to mood profiles compared to normoxia, characterized by an immediate increase in fatigue
Table 1. Cardiorespiratory parameters of TEmax performed at sea level.

\begin{tabular}{|c|c|c|c|}
\hline Variables & $\begin{array}{c}\text { Average } \pm \text { standard } \\
\text { deviation }\end{array}$ & $\begin{array}{l}\text { Minimum } \\
\text { values }\end{array}$ & $\begin{array}{l}\text { Maximum } \\
\text { values }\end{array}$ \\
\hline $\mathrm{VO}_{2}$ peak $\left(\mathrm{L}_{\mathrm{L}} \mathrm{min}^{-1}\right)$ & $3,46 \pm 0,44$ & 2,89 & 4,15 \\
\hline $\mathrm{VO}_{2}$ peak $\left(\mathrm{ml} . \mathrm{kg} \cdot \mathrm{min}^{-1}\right)$ & $49,67 \pm 5,78$ & 40,91 & 58,83 \\
\hline Maximum HR (bpm) & $191,25 \pm 7,77$ & 179,00 & 204,00 \\
\hline Maximum E $(\mathrm{L})$ & $140,99 \pm 19,91$ & 102,50 & 173,40 \\
\hline Maximum speed (km/h) & $15,92 \pm 1,31$ & 13,00 & 17,00 \\
\hline $\mathrm{VO}_{2} \mathrm{LV}-\mathrm{I}\left(\mathrm{L} \cdot \mathrm{min}^{-1}\right)$ & $2,49 \pm 0,26$ & 2,09 & 2,89 \\
\hline $\mathrm{VO}_{2} \mathrm{LV}-\mathrm{I}\left(\mathrm{mL} \cdot \mathrm{kg} \cdot \mathrm{min}^{-1}\right)$ & $35,83 \pm 3,77$ & 31,10 & 41,29 \\
\hline HR LV-I (bpm) & $155,75 \pm 9,47$ & 145,00 & 173,00 \\
\hline Speed LV-I (km/h) & $10,08 \pm 1,00$ & 9,00 & 12,00 \\
\hline $\mathrm{VO}_{2}$ LV-II $\left(\mathrm{L}_{\mathrm{L}} \mathrm{min}^{-1}\right)$ & $3,02 \pm 0,40$ & 2,50 & 3,80 \\
\hline $\mathrm{VO}_{2}$ LV-II (mL.kg.min $\left.{ }^{-1}\right)$ & $43,42 \pm 4,96$ & 35,20 & 49,32 \\
\hline HR LV-II (bpm) & $177,33 \pm 10,93$ & 157,00 & 194,00 \\
\hline Speed LV-II (km/h) & $13,25 \pm 1,14$ & 11,00 & 15,00 \\
\hline
\end{tabular}

Data presented as mean \pm standard deviation, referring to TEmax of 12 volunteers. $\mathrm{VO}_{2}$ Peak - peak oxygen consumption; HR- Heart rate; VE- ventilation; $\mathrm{VO}_{2} \mathrm{LV}-\mathrm{I}$ - oxygen consumption at the ventilatory threshold 1; HR $\mathrm{LV}-\mathrm{I}$ - Heart rate at ventilatory threshold $\mathrm{I} ; \mathrm{VO}_{2} \mathrm{LV}$-II - oxygen consumption at the ventilatory threshold 2; HR LV-II - Heart rate at ventilatory threshold II.

scores $\left(F_{(3.66)}=1.41, p<0.05\right)$ and mental confusion $\left(F_{(3.66)}=2.79, p<0.05\right)$ and then 30 minutes later a reduction of vigor $\left(_{(3.66)}=2.83, p<0.05\right)$.

The VAMS instrument only indicated differences in relation to time. In both experimental conditions maximum PE was capable of reducing anxiety scores $\left(F_{(3.66)}=10.83, p<0.05\right)$ immediately after the experiment.

In hypoxia, the dimensions of physical sedation $\left(F_{(3.66)}=19.94, p<0.05\right)$, mental sedation $\left(F_{(3.66)}=4.86, p<0.05\right)$, and other feelings and attitudes $\left(F_{(3.66)}=8.54, p<0.05\right)$, decreased immediately after the experiment and then after 30 minutes. In normoxia, immediately after the experiment physical sedation was reduced ( $p=0.001$ ) (Table 2).

An effect of time and group was observed in oxyhemoglobin saturation (Figure 3), $\left(F_{(3.66)}=22.10, p<0.05\right)$. In the hypoxia condition reduced saturation was observed immediately after the experiment $(p=0.0001)$ and 30 minutes later ( $p=0.00005$ ), when compared to baseline and 60 minutes ( $p=0.00005)$, and respective moments in normoxia. 


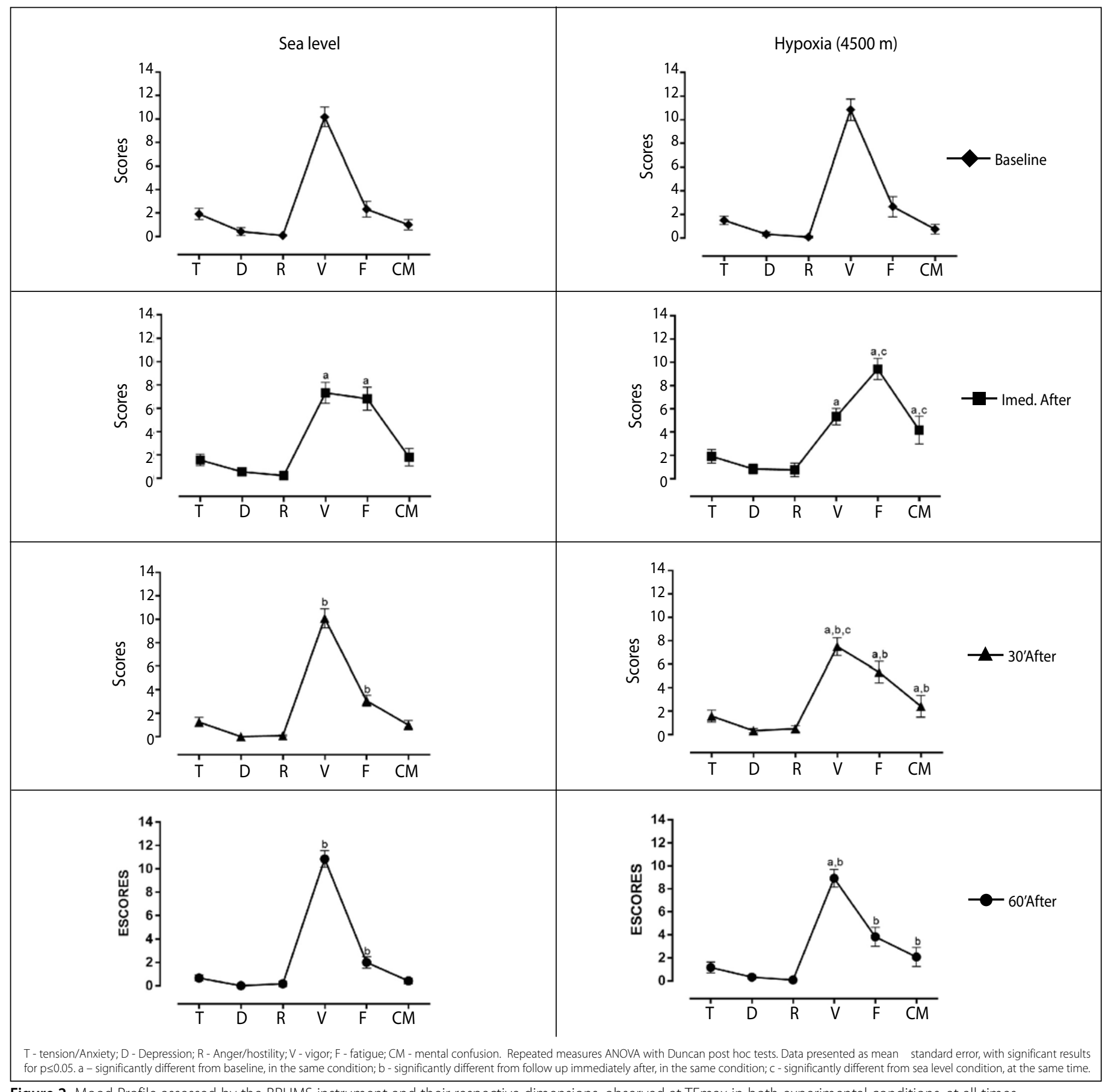

Figure 2. Mood Profile assessed by the BRUMS instrument and their respective dimensions, observed at TEmax in both experimental conditions, at all times.

Table 2. Mood Profile on the VAMS instrument and their respective dimensions, observed at TEmax in both experimental conditions, at all times.

\begin{tabular}{|c|c|c|c|c|c|c|c|c|c|}
\hline & & \multicolumn{4}{|c|}{ Sea Level } & \multicolumn{4}{|c|}{ Hypoxia (4500 m) } \\
\hline & & Baseline & Imed. After & 30 minutes & 60 minutes & Baseline & Imed. After & 30 minutes & 60 minutes \\
\hline \multirow{4}{*}{ VAMS } & Anxiety & $46,67 \pm 2,56$ & $35,11 \pm 3,22^{\mathrm{a}}$ & $43,27 \pm 3,67^{b}$ & $47,33 \pm 3,20^{b}$ & $45,55 \pm 3,73$ & $38,38 \pm 3,26^{a}$ & $47,13 \pm 4,02^{b}$ & $49,48 \pm 3,59^{b}$ \\
\hline & Physical sedation & $43,53 \pm 1,91$ & $36,57 \pm 3,08^{a}$ & $42,21 \pm 2,48^{b}$ & $44,62 \pm 1,80^{b}$ & $46,68 \pm 2,64$ & $32,66 \pm 3,39^{a}$ & $37,11 \pm 3,85^{a, b}$ & $39,81 \pm 3,63^{a, b}$ \\
\hline & Mental sedation & $35,27 \pm 3,16$ & $37,44 \pm 3,42$ & $41,09 \pm 2,76$ & $41,93 \pm 2,12$ & $43,24 \pm 2,96$ & $34,31 \pm 3,74^{a}$ & $34,01 \pm 3,09^{\mathrm{a}}$ & $37,44 \pm 3,79$ \\
\hline & OFA & $45,39 \pm 2,27$ & $41,47 \pm 2,64$ & $45,75 \pm 1,83$ & $46,67 \pm 1,75^{b}$ & $50,46 \pm 1,44$ & $40,58 \pm 3,75^{\mathrm{a}}$ & $43,21 \pm 3,40^{\mathrm{a}}$ & $45,56 \pm 3,01^{a, b}$ \\
\hline
\end{tabular}

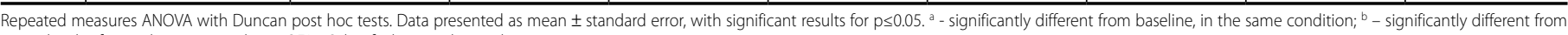
immediately after, in the same condition. OFA - Other feelings and attitudes.

An increase in blood lactate levels was observed immediately after the experiment and 30 minutes later compared to baseline and 60 minutes in both experimental conditions $\left(\mathrm{F}_{(3.51)}=158.73, \mathrm{p}<0.05\right)$. In addition, in terms of experimental conditions $\left(\mathrm{F}_{(3.51)}=4.25, \mathrm{p}<0.05\right)$, there was a marked increase immediately after the experiment of this metabolite in hypoxia compared to normoxia ( $p=0.006$ ) (Figure 4 ).

\section{DISCUSSION}

Hypoxia causes numerous and critical adjustments in mood and physiological variables, that are amplified by the completion of maximum PE.

Robust changes were observed on BRUMS dimensions during hypoxia, including increased fatigue, increased mental confusion, decreased vigor, and higher total mood disturbances. 


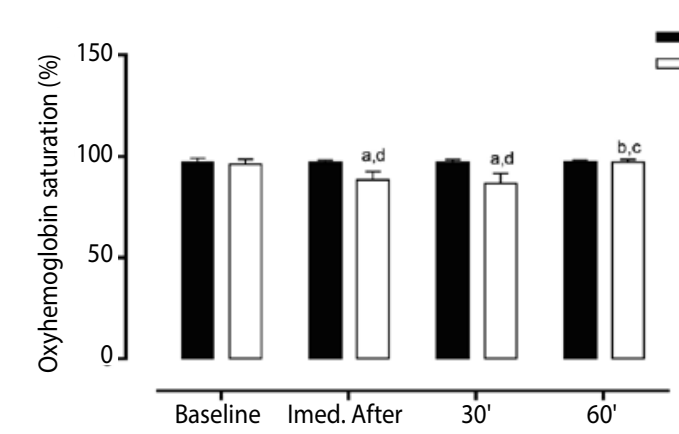

Figure 3. Oxyhemoglobin saturation observed in the TEmax, in both experimental conditions, at all times. Repeated measures ANOVA with Duncan post hoc tests. Data presented as mean \pm standard deviation-pattern, with significant results for $p \leq 0.05$. - different from baseline, in the same condition; ${ }^{b}$ - different from immediately after, in the same condition; ${ }^{c}$ - different from 30 minutes, in the same condition; $d$ - different from sea level condition, at the same time.

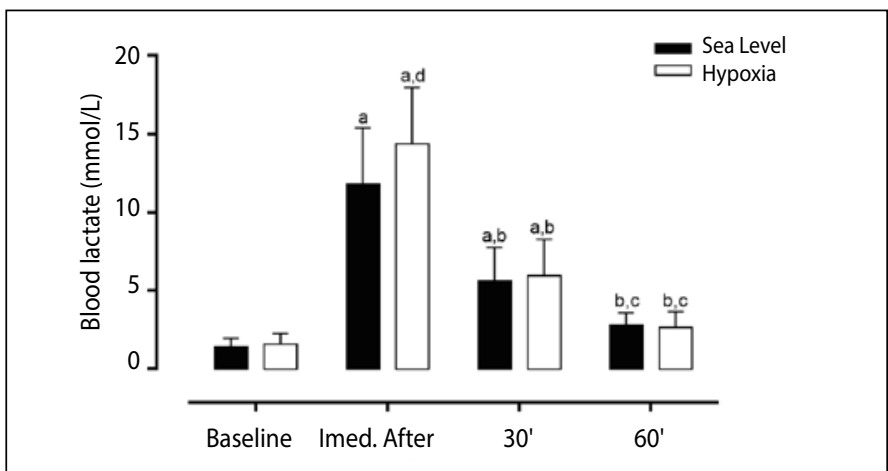

Figure 4. Concentration of blood lactate, observed in the TEmax in both experimental conditions, at all times. Repeated measures ANOVA with Duncan post hoc tests. Data presented as mean \pm standard deviation-pattern, with significant results for $p \leq 0.05$. - different from baseline, in the same condition; ${ }^{b}$ - different from immediately after, in the same condition; ${ }^{c}$ - different from 30 minutes, in the same condition; ${ }^{d}$ - different from sea level condition, at the same time.

These findings corroborate a study by Lemos et al. ${ }^{9}$, that observed that the scores BRUMS on depression, anger, and fatigue were higher in individuals exposed to hypoxia compared to normoxia. In turn, vigor scores were lower in hypoxia compared to normoxia.

The losses on the affective dimensions observed in our study are consistent with previous data that emphasizes that hypoxia at altitudes of $4.500 \mathrm{~m}$ can cause cognitive impairments in attention, short-term memory, arithmetic skills, and decision-making, as well as psychobiological changes, in particular increases in euphoria, irritability, hostility, and neuropsychological impairment ${ }^{11}$.

Furthermore, not only do high altitudes influence mood states, but Li et al. ${ }^{19}$ have highlighted the interference of hypoxia (simulated at $2,800 \mathrm{~m}$ ) on mood uncovered during the hour of this condition. These individuals showed a gradual increase in stress and fatigue, and a reduction in vigor, that was aggravated by the gradual ascent to a high altitude.

The affective changes evaluated by the VAMS instrument further support these findings. In hypoxia, a reduction in scores was exhibited in physical sedation, mental sedation, and other feelings and attitudes, particularly immediately and 30 minutes after the experiment indicating an increase in alertness during exposure to hypoxia.

These results corroborate Weiss et al. ${ }^{20}$ who described the effects of sub-acute intermittent hypoxia (at an altitude of $3.962 \mathrm{~m}$ ) on various cognitive functions, and in particular alertness. The absence of significant deficits in objective alertness and attention, main findings of this study, can be explained by the reduced availability of oxygen during hypoxia, that plays a role in the synthesis of catecholamines, the primary hormones responsible for increases in alertness ${ }^{21}$.

Moreover, it is noteworthy that there were reduced scores in anxiety in both experimental conditions immediately after the completion of TEmax. These results suggest that despite exposure to hypoxia, maximum PE still exerted an anxiolytic effect ${ }^{22}$; unlike what was observed after moderate PE in the same condition ${ }^{23}$. Extended exposure to hypoxia, intensity of the effort and within subject variability all serve as plausible explanations for the varied results 3 3,23.

The reduced oxyhemoglobin saturation immediately and 30 minutes after exposure to the hypoxia condition are indicative of a return to normoxia and the subsequent normalization of oxyhemoglobin saturation.

In agreement with these findings, Mollard et al ${ }^{24}$ found a larger reduction of oxyhemoglobin saturation in the trained group compared to a untrained group that underwent a maximal test of incremental load in a condition of simulated hypoxia at 5 altitudes. One of the objectives of this study was to evaluate whether the reduction of the maximum $\mathrm{VO}_{2}$ of participants exposed sharply to hypoxia could only be explained by a decrease in oxyhemoglobin saturation or by the behavior of the HR. The study demonstrated that oxyhemoglobin saturation is a strong predictor of maximum $\mathrm{VO}_{2}$. This is primarily because of the limitations of the alveolar-capillary diffusion that is the outcome of an increase in cardiac output, reducing the transit time of red blood cells in pulmonary capillaries.

Differences between the experimental conditions were found in the variables vigor, fatigue, mental confusion, saturation of oxyhemoglobin, and blood lactate levels highlighting the impact of hypoxia on mood and physiological responses.

The blood lactate response to incremental PE until fatigue is well established. While its concentration is maintained close to $1 \mathrm{mmol} / \mathrm{L}$ in conditions of low to moderate work load, in situations of greater loads there is a non-linear increase to maximum $\mathrm{VO}_{2}{ }^{25}$.

Blood lactate varied similarly in both experimental conditions, but was accentuated more in hypoxia, particularly immediately after the condition. This behavior differs from other studies highlighting the intriguing phenomenon of the lactate paradox. The lactate paradox refers to an unexpected reduction of blood lactate concentration during PE in individuals recently exposed and/or acclimatized to high altitudes ${ }^{26}$.

In contrast with this explanation and consistent with our results, Reeves et al. ${ }^{27}$ argued that the accumulation of blood lactate during PE increases in higher altitudes, but reduces after acclimatization. This is paradoxical because that this occurs without any change in the delivery of oxygen to the muscle.

This finding was also observed by Van Hall et al. ${ }^{28}$, where individuals at sea level engaged in a regimen of incremental PE until exhaustion, had increased arterial blood and muscle lactate concentrations in an acute exposure to hypoxia (simulated at $4100 \mathrm{~m}$ ) condition.

This behavior could be possibly explained by anaerobiosis, increased glycolytic flow ${ }^{29}$, and elevated levels of catecholamines ${ }^{30}$. However, despite the efforts of numerous studies, there is a lack of conclusive and convincing evidence for this phenomenon.

\section{CONCLUSIONS}

The particularities of a hypoxic environment associated with maximum PE can result in decreases in mood and physiological responses that possibly could negatively modulate physical performance.

\section{ACKNOWLEDGMENTS/FINANCING}

The authors would like to thank the scientific support of Everald Vancouler and the technical and financial support of the AFIP, FAPESP, CNPq (475074/2011-4).

All authors declare no potential conflict of interest related to this article. 
AUTHORS' CONTRIBUTIONS: Each author made significant individual contributions to this manuscript. SQCG (0000-0001-9983-8812)* conception, design, collection, analysis and interpretation of data, writing of the manuscript. JFTS (0000-0002-4599-7217)* conception, design, collection and analysis of data. MTM (0000-0003-3896-2208)* financing and supervision of work. ST (0000-0002-3804-8865)* financing and supervision of work. RVTS (0000-0001-7010-2799)* analysis and interpretation of data, revision of the manuscript. HKMA (0000-0001-6648-0957)* conception, design, analysis and interpretation of data, writing and reviewing the manuscript, funding and supervising the work. *ORCID (Open Researcher and Contributor ID).

\section{REFERENCES}

1. Frisancho AR. Developmental Functional Adaptation to High Altitude: Review. Am J Hum Biol. 2013;25(2):151-68.

2. Virués-Ortega J, Garrido E, Javierre C, Kloezeman K. Human behaviour and development under high-altitude conditions. Dev Sci. 2006;9(4):400-10

3. Mazzeo RS. Physiological Responses to Exercise at Altitude. Sports Med. 2008;38(1):1-8.

4. Verges $S$, Bachasson D, Wuyam B. Effect of acute hypoxia on respiratory muscle fatigue in healthy humans. Respir Res. 2010;11(1):109.

5. Chapman RF, Levine BD. The effects of hypo and hyperbaria on sport performance. In: Garrettwe, Kirkendall JT (Orgs). Exercise and Sports Science. Philadelphia: Ed. Lippincott, Williams \& Wilkins; 2000. p.447-58.

6. Bolmont B, Thullier F, Abraini JH. Relationships between mood states and performances in reaction time, psychomotor ability and mental efficiency during a 31-day gradual decompression in a hypobaric chamber from sea level to 8848 m equivalent altitude. Physiol Behav. 2000;71(5):469-76.

7. Bonnon M, Noel-Jorand MC, Therme P. Criteria for psychological adaptation to high-altitude hypoxia. Percept Mot Skills. 1999;89(1):3-18.

8. Dykiert D, Hall D, Van Gemeren N, Benson R, Der G, Starr JM, et al. The effects of high altitude on choice reaction time mean and intra-individual variability: results of the Edinburgh Altitude Research Expedition of 2008. Neuropsychology. 2010;24(3):391-401.

9. Lemos VA, Antunes HK, Dos Santos RVT, Lira FS, Tufik S, De Mello MT. High altitude exposure impairs sleep patterns, mood, and cognitive functions. Psychophysiology. 2012;49(9):1298-306.

10. Kobrick JL, Johnson RF. Effects of hot and cold environments on military performance. In: Galand RA Mangelsdorff D (Orgs). Handbook of Military Psychology. New York: Ed. Wiley; 1991. p. 215-32.

11. Bahrke MS, Shukitt-Hale B. Effects of altitude on mood, behaviour and cognitive functioning: a review. Sports Med. 1993;16(2):97-125.

12. Hogan CL, Mata J, Carstensen LL. Exercise holds immediate benefits for affect and cognition in younger and older adults. Psychol Aging. 2013;28(2):587-94.

13. Berger BG, Motl RW. Exercise and mood: A selective review and synthesis of research employing the profile of mood states. J Appl Sport Psychol. 2000;12(1):69-92.

14. Jones AM, Doust JH. A 1\% treadmill grade most accurately reflects the energetic cost of outdoor running. J Sports Sci. 1996;14(4):321-7.

15. Terry PC, Lane AM, Fogarty GJ. Construct validity of the Profile Of Mood States - Adolescents for use with adults. Psychol Sport Exerc. 2003;4(2):125-39.

16. McNair DM, Lorr M, Droppleman LF. Profile Mood States: Manual. San Diego: Education and Industrial Testing Service;1971.
17. Rohlfs ICPM, Rotta TM, Luft CDB, Andrade A, Krebs RJ, Carvalho T. A Escala de Humor de Brunel (Brums): Instrumento para Detecção Precoce da Síndrome do Excesso de Treinamento. Rev Bras Med Esporte. 2008;14(3):176-81.

18. Bond AJ, Lader MH. The use of analogue scales in rating subjective feelings. Br J Med Psychol. 1974;47(3):211-8.

19. Li XY, Wu XY, Fu C, Shen XF, Wu YH, Wang T. Effects of acute mild and moderate hypoxia on human mood state. Space Med Med Eng (Beijing). 2000;13(1):1-5.

20. Weiss MD, Tamisier R, Boucher J, Lynch M, Gilmartin G, Weiss JW, et al. A pilot study of sleep, cognition, and respiration under 4 weeks of intermittent nocturnal hypoxia in adult humans. Sleep Med. 2009;10(7):739-45

21. Kumar GK. Hypoxia. 3. Hypoxia and neurotransmitter synthesis. Am J Physiol Cell Physiol 2011;300(4):C743-51.

22. Carek PJ, Laibstain SE, Carek SM. Exercise for the treatment of depression and anxiety. Int J Psychiatry Med. 2011;41(1):15-28.

23. Souza JFT, Giampá SQC, Lemos VA, Santos SM, Silva ET, de Mello MT, et al. Exercise performed at hypoxia influences mood state and anxiety symptoms. Motriz. 2015; 21(2):177-184

24. Mollard P, Woorons X, Letournel M, Cornolo J, Lamberto C, Beaudry M, et al. Role of maximal heart rate and arterial $\mathrm{O} 2$ saturation on the decrement of $\mathrm{VO} 2 \mathrm{max}$ in moderate acute hypoxia in trained and untrained men. Int J Sports Med. 2007;28(3):186-92.

25. Astorino TA, Ghiasvand F, Robergs R. Acute Hypoxia Alters Lactate Threshold in Chronic Altitude Residents J Exerc Physiol. 2004;7(2):6-15

26. West JB. Point: the lactate paradox does/does not occur during exercise at high altitude. J Appl Physiol (1985). 2007;102(6):2398-9.

27. Reeves JT, Wolfel EE, Green HJ, Mazzeo RS, Young AJ, Sutton JR, et al. Oxygen transport during exercise at altitude and the lactate paradox: lessons from Operation Everest II and Pikes Peak. Exerc Sport Sci Rev. 1992;20:275-96.

28. Van Hall G, Lundby C, Araoz M, Calbet JA, Sander M, Saltin B. The lactate paradox revisited in lowlanders during acclimatization to $4100 \mathrm{~m}$ and in high-altitude natives. J Physiol. 2009;587(Pt 5):1117-29.

29. Reeves JT, Groves BM, Sutton JR, Wagner PD, Green HJ, Cymerman A, et al. Adaptations to hypoxia: Lessons from Operation Everest II. In: Simmons DH (Org). St. Louis: Ed. Mosby Year Book; 1991. p.23-50.

30. Hughson R, Green HJ, Sharratt M. Gas exchange, blood lactate, and plasma catecholamines during incremental exercise in hypoxia and normoxia. J Appl Physiol (1985). 1995;79(4):1134-41. 